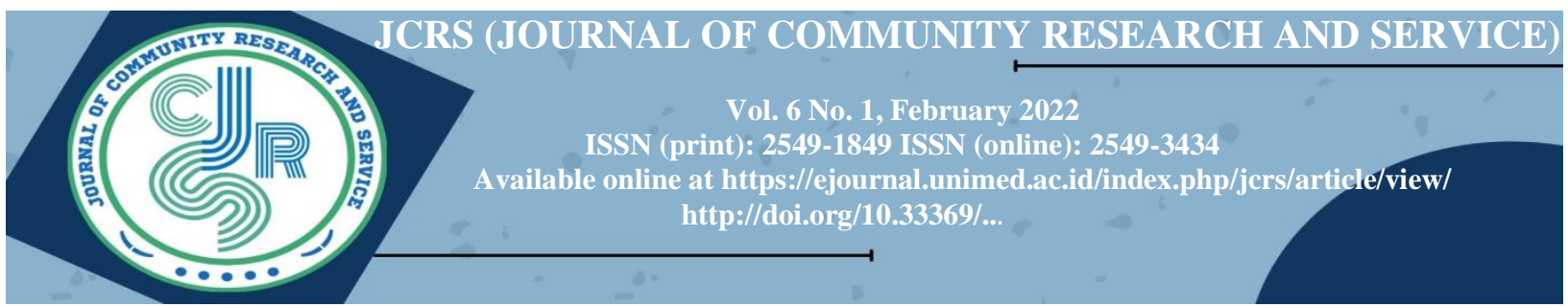

\title{
Wasted of Young Coconut Shell and Skins as an Alternative Polybag and Charcoal Bricket
}

\section{${ }^{1}$ Choms Gary Ganda Tua Sibarani,2 Sondang Aida Silalahi, ${ }^{3}$ Nelly Armayanti, 4 Tuti Sriwedari}

\author{
${ }^{1,2,3,4}$ Universitas Negeri Medan \\ Igary.sibarani@unimed.ac.id
}

\begin{abstract}
The community service activities carried out by the team on this occasion aim to provide several alternative side incomes for young coconut entrepreneurs. Some of the problems partners face in this regard are specifically in: a). Waste of young coconut shells and young coconut shells that are just thrown away and piled up beside/behind the young coconut business; b) the bookkeeping system is still traditional; there are even partners who did not record the books beforehand. Specific targets or solutions expected in this community service area). Partners can process young coconut waste into a new source of income, namely by making used coconut shells into natural and environmentally friendly pots/polybags by planting aglaonema flowers, and b). The scraps of peel and fragments of young coconut shell waste can be used as a fuel substitute for charcoal or briquettes. The service team handed over TTG in the form of closed burning barrels from used barrels for optimal combustion and simple financial training to determine the income from selling young coconuts to partners. Method of Implementation This service is carried out by carrying out the initial approach method, training, and mentoring on how to manufacture the finished product so that the alternative side income can be achieved maximally. The outputs produced in this activity are as follows: a) print and online mass media publications; (b) activity videos uploaded on youtube, and (c) articles in national journals with ISSN online and in print (d) trademarks (billboards/banners) creative designs, social media and also business location points on google maps.
\end{abstract}

Keywords: Shell Young coconut, Polybag, Charcoal Briquettes

Article history: Received:22-11-2021; Revised:22-12-2021; Accepted:22-02-2022; Available online: 26-02-2022

How to cite this article: Sibarani, C.G.G.T., Silalahi, S.A., Armavanit N., and Sriwedari, T. (2022) Wasted of Young Coconut Shell and Skins as an Alternative Polybag and Charcoal Bricket. Journal of Community Research and Service, 6(1), $\mathrm{xxx}-\mathrm{xxx}$. https://doi.org/10.14710/ijred.x.X.Xxx-Xxx

\section{Introduction}

As a country located in the tropics, Indonesia is one of the countries that have the largest coconut tree area in the world. However, the unfortunate thing is that Indonesia has not been able to raise the economic welfare of coconut farmers. In contrast to the Philippines, which only has a land area far below Indonesia's, it is able to earn higher foreign exchange profits than Indonesia. The Philippines' success in earning foreign exchange is fantastic because it has succeeded in diversifying coconuts into many processed products. [1]. The area of coconut plantations in Indonesia in 2005 reached 3.29 million ha, with the number of productive plants reaching $73.6 \%$ [2]. Coconut flesh is the main component that can be processed into various derivative products. In the processing, coconuts produce shells which are considered as residual waste. Coconut shell waste, either from coconut processing industries or household consumption, is generally thrown away. Although classified as organic waste, coconut shell waste is not easily decomposed by microorganisms due to its hard nature. In addition, coconut shells have a fairly large weight and size. This resulted in the disposal of coconut shell waste, often buildup.

As one of the sub-districts in Medan City, Medan Helvetia District has seven villages, namely Cinta Damai Dwi Kora, Helvetia, Central Helvetia, East Helvetia Sei Sikambing C II, Tanjung Gusta for the road 
area for young coconut SME entrepreneurs, more precisely in the Griya area. The Dome, Jalan Captain Sumarsono Gaperta, Kelambir Lima, the Muslim captain, and the surrounding areas are SMEs for young coconut traders for Medan. Efforts to utilize coconut shell waste that has been cultivated currently include processing it as charcoal. For the activated charcoal industry, the type of shell that meets the quality requirements is the old one (11-12 months) because the wood is hard and the water content is low so that in the cooking process, the maturation will take place well and evenly. Young coconut shells (7-10 months) can also be used as raw material for making charcoal, but they have to go through a long process and produce poor quality charcoal, so the charcoal industry rarely uses them.

Based on these considerations, this study only included young coconut shells as the object of study because the utilization opportunities were more limited than old coconut shells, which many people have used as charcoal briquettes. Another opportunity for utilizing coconut shell waste is to manufacture environmentally-friendly polybags made from unused young coconut shells. Medan Helvetia District fully supports the development of Small and Medium Enterprises (SMEs) managed by the community to become even more developed, one of the SMEs, namely the one in Medan Helvetia District, is an MSME partner "Es Kelapa Muda Roby" Mrs. Junita br manages this SME. Linga" is located on Jl. T. Amir Hamzah, Helvetia District, Medan City, North Sumatra Province.

This SME utilizes the location around the "overhang" by the roadside Tengku Amir Hamzah (Seputaran Griya Riatur) to sell Young Coconut Water, while for the financial accounting process, Mrs. details of the accounting for the sale of young coconut water, just remembering that the expenditure for the purchase of young coconuts is around Rp. 935.000, -he did not record the profit in detail. This mother's business is assisted by her daughter and her husband, where they have been selling for about 15 years.

For the second partner, namely the "Es Kelapa Muda Joss" Own Business by Ibu Suci br. Laia, not far from where Ibu lingga sells. The supply of this young mother's coconut is entirely selling well until late at night, the average buyer directly buys young coconuts that are cut into initial rounds, they almost rarely receive drinks in a glass, so the profit is quite large. But on the other hand, Mrs. Laia also does not keep simple bookkeeping, and she only carries a small bag to carry for return if there are buyers who need change. Based on the data above, there are several problems that must be addressed; improvements can be made by bringing in experts from each of the weaknesses that exist in the young coconut trading business in the two mother's businesses, namely Mrs. Lingga and Mrs. Suci Laia, the experts can be from practitioners and academics, which is more focused on financial bookkeeping on a daily and monthly basis, innovation (utilization) of shell and shell waste and young coconut shells that are just thrown away. So from the facts in the field, it is hoped that it can solve the existing problems so that the Young Coconut Business SMEs in the Medan Helvetia District can be more prosperous and prosperous.

\section{Method}

The implementation method is carried out as follows: making preparations, this preparatory stage carries out several activities, namely: (a) socialization of the Community Service program, with partners at the place of business (b) conducting observations and interviewing partners and conducting discussions to solve existing problems; (c) determining the schedule of activities; (d) mutual commitment between service and Partners; and (e) preparing facilities and infrastructure to support the implementation of Community Service activities, (f) Focus Group Discussions (FGD) conducted from the beginning to the end with Partners, (g) training, education, and assistance on the importance of financial bookkeeping in an effort, (h) training, education, and mentoring on how to process young coconut shells and skins into environmentally friendly polybags using the innovation of a cask that is designed in such away.

\section{Findings and Discussion}

This Community Service activity produces the following outputs: 1) innovation of burning place for processing young coconut shells 2) Polybags from young coconut shells and 3) financial bookkeeping guidebooks; the following products are produced during community service activities: 


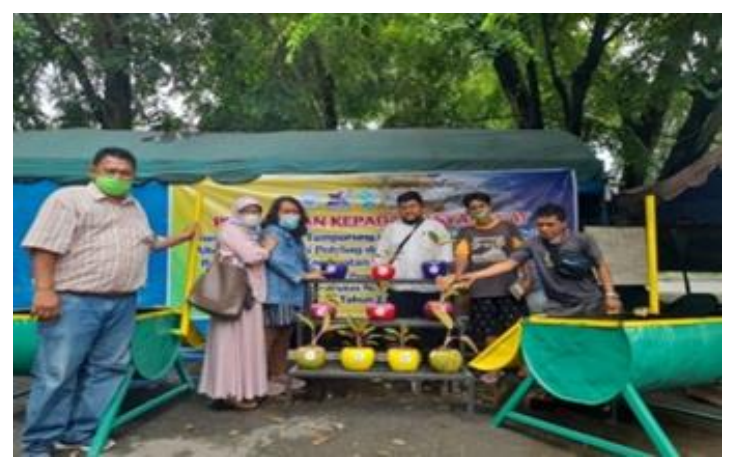

Fig. 1. Polybag products from young coconuts accompanied by the PKM Team.

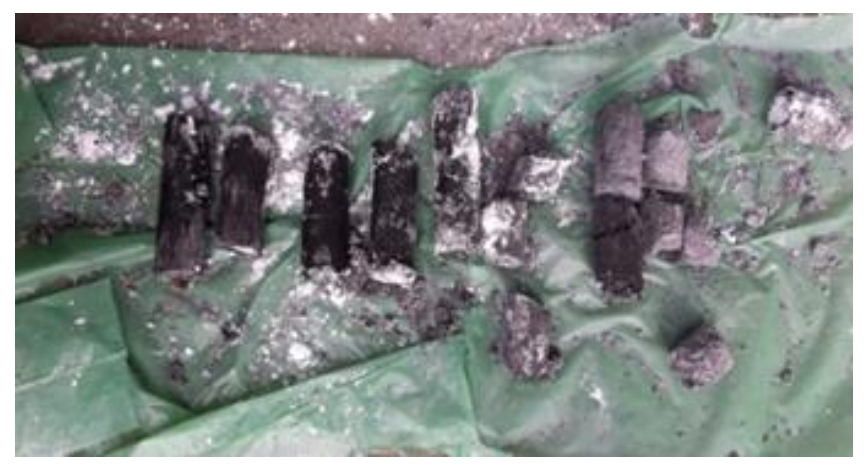

Fig. 2. Charcoal Briquettes from Young Coconut Shells.

Training on processing, training, education, assistance on the importance of accounting for financial statements in a business, and handover of financial guidebooks and financial bookkeeping. Provide a Trade Business Name design in the form of a Banner Screen that can increase revenue because it is easy for customers to remember. Moreover, register on Google maps so that the young coconut SMEs business location for these partners is easy to reach.

The service team has also produced several outputs as part of contracts and marketing for partners, which were published digitally on the online media OKMedan.com News on July 14, 2021, and also daily alert on July 19, 2021; besides that, the team also uploaded this activity. On the YouTube page with the link and also get the copyright from the idea of processing young coconuts into charcoal briquettes and polybags.

\section{Conclusion}

This Community Service activity aims to improve the quality of financial bookkeeping and the quality of processing young coconut shells in partner businesses, namely the young coconut ice business. The problem faced by partners here is that young coconut shells are just wasted. Week to dispose of piles of young coconut shells, and financial management can be said to have not been maximized where only used paper is used.

The solutions offered here, Partners are given training, education, assistance, socialization, and delivery of Appropriate Technology (TTG) regarding the problems faced by Partners. Creative training on how to make young coconut shells as a substitute for reusable polybags and young coconut husk pulp by providing training on how to process them, training, education, and assistance on the importance of bookkeeping financial statements in a business handover of financial guidebooks and bookkeeping ledgers finance. Provide Trade Business Name in the form of Banner Screen Printing. And register on Google maps, so customers can easily reach the locations of these two partners. 


\section{References}

[1] Indrawati S, Suyatno S. Pemanfaatan Limbah Tempurung Kelapa Muda sebagai Alternatif Material Akustik. JFA (Jurnal Fisika dan Aplikasinya). 2017;13(3):115 - 118.

[2] Junandi S. Analisis sitiran artikel jurnal luar negeri pada laporan penelitian di Lembaga Penelitian dan Pengabdian kepada Masyarakat UGM yang dibiayai Badan Litbang Pertanian Departemen Pertanian Tahun 2007. Berkala Ilmu Perpustakaan dan Informasi. 2010;6(1). 